\title{
1 Å skjevdele alt? En mulighet i de særegne oppgjørene
}

Katrine Kjærheim Fredwall (cand.jur. 1995, phd 2019) er gjennomføringsstipendiat ved institutt for privatrett, Universitetet i Oslo og lovrådgiver i Lovavdelingen, Justis- og beredskapsdepartementet. Epost: katrine.fredwall@jus.uio.

\section{Sammendrag:}

Artikkelen behandler ekteskapsloven § 59 tredje ledd og retten til å skjevdele også det som er skapt underveis i ekteskapet der sterke grunner tilsier det. Det er ofte pekt på at det er en høy terskel for å anvende bestemmelsen. I artikkelen konkluderes det med at det gir en mer treffende beskrivelse å si at bestemmelsen bare kan anvendes i de mer atypiske situasjonene.

Rettspraksis tilsier at bestemmelsen særlig anvendes der dette er nødvendig for å sikre ektefelles eller barns levekår, for å sikre at midler som i tråd med partenes forutsetninger reelt sett er samlivet uvedkomment, forblir udelt og for å kunne skape balanse der den ene kan holde midler utenfor deling som følge av påbud fra giver eller arvelater mv. Rettspraksis viser at retten til skjevdeling etter tredje ledd er en korreksjonsmekanisme som oftest anvendes for å skape et mer økonomisk balansert resultat der det er få midler å fordele. Nøkkelord: skjevdeling, sterke grunner, terskel, menneskeretter, ekteskapsloven § 59 tredje ledd.

\section{Det rettslige utgangspunktet og problemstilling}

Retten til å holde utenfor deling det man eide fra før eller har mottatt som arv og gave underveis i ekteskapet etter ekteskapsloven § 59 første ledd er praktisk, diskutert og omdiskutert. Retten til å holde vanlige felleseiemidler skapt underveis i ekteskapet utenfor deling, har fått mindre oppmerksomhet. I artikkelen her skal ekteskapsloven § 59 tredje ledds praktiske og faktiske bruk analyseres på bakgrunn av en samlet rettspraksis. 
Det følger av ordlyden i ekteskapsloven $§ 59$ tredje ledd at dersom «sterke grunner» taler for det, «kan» en ektefelle gis rett til å holde «hele eller deler av verdien av felleseie» som ikke er omfattet av første ledd, utenfor deling. Dette er en rett til «å holde utenfor deling» hvilket forutsetter at ektefellen ved skjæringstidspunktet er eier av positive nettoverdier som kan beholdes udelt. Bestemmelsen hjemler ikke rett til å få noe fra den andre, men en skjønnsmessig adgang til å slippe å dele sitt eget.

Høyesterett har understreket at dette er en snever unntaksregel: ${ }^{1}$

«Denne bestemmelsen gir - dersom «sterke grunner taler for det» - hjemmel for å skjevdele verdier som er ervervet under ekteskapet på annen måte enn ved arv og gave. Høyesterett har i flere avgjørelser gitt uttrykk for at $\S 59$ annet ledd er en snever unntaksregel, jf. blant annet Rt1999-177. Det er ikke tvilsomt at dette i minst like høy grad gjelder bestemmelsen i tredje ledd».

Under lovbestemmelsens forberedelser understreket utvalget at tredje ledd gir $\mathrm{i}$ «helt særlige tilfelle» adgang til å utta forlodds midler ervervet under ekteskapet. ${ }^{2}$ I proposisjonen ble det påpekt at bestemmelsen var ment som en «snever unntaksregel» og at dette var markert ved valget av formuleringen «sterke grunner». ${ }^{3}$ Justiskomitéen understreket også at det måtte være adgang til en slik skjevdeling i «særlige tilfeller», slik det var foreslått. ${ }^{4}$

Formålet med bestemmelsen var å oppnå rimelige skifteoppgjør. Det uttales eksplisitt i proposisjonen at der skjevdelingen etter nåværende tredje ledd «vil gi urimelige utslag, må likedeling finne sted $» .{ }^{5}$ Proposisjonens omtale av bestemmelsen og videre eksemplifisering tilsier at formålet med bestemmelsen er å gi et verktøy for å sikre rimelighet og balanse. ${ }^{6}$ Proposisjonen nevner mange situasjoner der korreksjon etter tredje ledd kan være nødvendig for å sikre rimelige resultat. Det nevnes blant annet at bestemmelsen kan anvendes for å lindre konsekvensene der den ene har likedelingsmidler, mens den andre har skjevdelingsmidler, der den ene er arbeidsfør og den andre ikke, der den ene har opparbeidet (gode) pensjonsrettigheter og den andre ikke, der den ene har betydelig gjeld som ikke har kommet den andre til gode, der den ene har misbrukt retten til å råde over felleseiet, der den ene har fors $\varnothing$ rget den andre under utdanning uten å rukket få noe tilbake og der den ene har sine midler bundet i en virksomhet som skal fortsette og at dette gjør det

\footnotetext{
${ }^{1}$ Rt. 2002 s. 1596 på s. 1602 . Se også Rt. 2001 s. 572 og Rt. 1999 s. 177 om annet ledd.

2 NOU 1987: 30 s. 130 annen spalte.

${ }^{3}$ Ot.prp. 28 (1990-1991) s. 122

${ }^{4}$ Innst. O. nr. 71 (1990-1991) s. 15

${ }^{5}$ Ot.prp. 28 (1990-1991) s. 69. første spalte.

${ }^{6}$ Ot.prp. 28 (1990-1991) s. $69-70$.
} 
vanskelig å utløse ektefellen fullt ut. Departementet antok også at det ville være mest aktuelt med delvis skjevdeling, selv om bestemmelsen også hjemler hel skjevdeling. Til tross for at dette formuleres som en snever unntaksregel, pekes det i proposisjonen på et vidt bruksområde der bestemmelsen kan brukes til å oppnå balanse og rimelighet.

I Lødrup/Sverdrup understrekes det dels at skjevdelingsretten etter tredje ledd er «meget snever» og at den er en "sikkerhetsventil». ${ }^{7}$ I kommentarutgaven understrekes det også at er en «snever unntaksbestemmelse» og at normen er «antakelig strengere» enn i annet ledd. ${ }^{8}$ Også note 229 til ekteskapsloven i Norsk Lovkommentar blir det om tredje ledd uttalt at «det skal nok mer til enn etter annet ledd». ${ }^{9}$ I kommentarutgaven nevnes mange av de bruksområdene som er omtalt i proposisjonen, jf. over. Det pekes samme sted også på at det etter tredje ledd er en forutsetning at ektefellen krever utvidet skjevdeling. Det uttales videre at det «må også ellers» kunne skje en samlet vurdering etter første og tredje ledd. ${ }^{10}$ Eeg ser også første og tredje ledd som supplerende grunnlag for skjevdeling og har blant annet pekt på at det er naturlig å anvende tredje ledd som hjemmel for en eventuell skjevdeling av avkastning som har blitt til underveis i ekteskapet. ${ }^{11}$

\section{Menneskerettslige skranker?}

Menneskerettene verner retten til selvbestemmelse og beskytter retten til å inngå avtaler også på dette rettsområdet, jf. FNs kvinnekonvensjon (KDK) artikkel 15. I tillegg utgjør artikkelen en viss skranke mot urimelige avtaler. Der partene ikke har inngått avtale, kan imidlertid menneskerettene også utgjøre en skranke eller en tolkningsfaktor for den deklaratoriske lovgivningen på området. Det skal ikke utelukkes at menneskerettene kan utgjøre en skranke for lovgiver på dette området, menneskerettene som tolkningsfaktor for familieformuerettens mange skjønnsmessige bestemmelser, er imidlertid særlig praktisk. ${ }^{12}$

KDK artikkel 16 sikrer kvinners og menns like rett til den formuen som er akkumulert underveis i samlivet. En likedelingsregel modifisert av en skjevdelingsregel slik vi har i Norge,

\footnotetext{
${ }^{7}$ Lødrup/Sverdrup (2016) "Familieretten" s. 280.

${ }^{8}$ Holmøy/Lødrup (2001) «Ekteskapsloven» s. 402.

${ }^{9}$ LA-2018-121298

${ }^{10}$ Holmøy/Lødrup (2001) s. 403.

${ }^{11}$ Eeg (2007) «Skjevdeling - Avkastning, verdistigning og gjeld» i Tidsskrift for familierett, arverett og barnevernrettslige spørsmål, s. 82-118, på s. 117 og Eeg (2006) «Deling av ektefellers formuer ved separasjon og skilsmisse» s. 435

12 Fredwall (2019) «Familieformuerettens korreksjonsmekanismer» s. 162 - 179, 231 - 237 og 335 - 336.
} 
er i utgangspunktet i tråd med den delingsforventningen som kan tolkes ut av artikkel 16. Artikkelen krever ikke at alt ektefellene eier skal deles. Artikkelen slik den er tolkes av FNs kvinnekomité krever imidlertid en reell og effektiv deling av det som er skapt underveis i ekteskapet. ${ }^{13}$ For å besvare et spørsmål om etterlevelse av forpliktelsene er det derfor nødvendig å unders $\varnothing$ ke skjevdelingsreglenes virkninger i praksis. Det interessante med regelen i tredje ledd $\mathrm{i}$ et menneskerettsperspektiv er at den etter ordlyd utvilsomt er i strid med delingsforventningen i artikkel 16. Tredje ledd sikrer at midler som er opptjent underveis i ekteskapet, kan holdes utenfor deling. En unders $\varnothing$ kelse av praksis er derfor nødvendig for å vurdere om regelens effekt likevel er slik at den ikke strider mot artikkel 16, jf. punkt 3 under.

Staten og statens organer er også forpliktet til å legge barnets beste til grunn som et grunnleggende hensyn i alle saker som berører barnet, jf. barnekonvensjonen artikkel 3. ${ }^{14}$ Jeg skal ikke behandle menneskerettene mer inngående her, men vil peke på bruksområdet for slike bestemmelser underveis i behandlingen av tredje ledd i artikkelen her.

\section{Analyse av rettspraksis der $§ 59$ tredje ledd anvendes}

\subsection{Problemstilling}

Punkt 1 over tilsier at $\S 59$ tredje er forstått som en snever unntaksbestemmelse som kan anvendes bare der sterke grunner tilsier det. Det spørsmålet som reises i denne artikkelen er imidlertid om «snever» først og fremst sier noen om terskelen for å ta den i bruk eller om snever heller sier noe om bestemmelsens bruksområde. Dernest reises det spørsmål om det er holdepunkter for at det «antakelig» skal mer til å vinne fram med hjemmel i tredje ledd enn annet ledd? For å kunne tegne et mer presist bilde av regelen har jeg analysert en samlet rettspraksis på området.

\subsection{Metode}

Analysen i artikkelen er basert på samtlige publiserte, sivile dommer kunngjort på Lovdata. Søk ble foretatt i basen sivile dommer i Lovdata og inkluderer alle tre instanser og hele perioden fra lovens ikrafttredelse og frem til sommer 2019. Det ble benyttet funksjonen avansert søk og søkt på lovhenvisningen «ekteskapsloven $\S 59 »$, samt «tredje+ledd» og «sterke+grunner». Søket ble foretatt i fulltekst. Søket gav 74 treff. En nærmere manuell

\footnotetext{
${ }^{13}$ KDK artikkel 16 jf. artiklene 1 til 3 og CEDAW/C/GC/29 (2013), avsnitt 45

${ }^{14}$ Fredwall (2019) s. 426 - 440
} 
gjennomgang av materialet tilsa imidlertid at retten kun hadde tatt spørsmålet opp til realitetsbehandling i om lag halvparten av sakene. Det innebærer at dommer der bestemmelsen bare var omtalt, henvist til eller påberopt, men uten at retten tok stilling til spørsmålet, ble sortert ut av materialet. I tillegg ble tidligere retters avgjørelse av samme spørsmål tatt ut. Hver sak er derved bare med en gang og da representert ved behandlingen i høyeste instans. Da materialet var sortert på denne måten, gjensto 30 dommer egnet for en nærmere analyse.

\subsection{Funn}

I doktoravhandlingen konkluderte jeg med at ekteskapsloven $\S 59$ tredje ledd trådte frem som «en vesentlig sikkerhetsventil for de atypiske forholdene». ${ }^{15}$ Formålet med analysene i dette punktet er å kunne beskrive regelen. Hvor praktisk er bestemmelsen som sikkerhetsventil?

I de 30 sakene der retten tok stilling til ekteskapsloven $§ 59$ tredje ledd, ble det gitt dom for en utvidet rett til skjevdeling i 8 av de 30 sakene. Dette innebærer at parten vant frem på dette grunnlaget i 27 prosent av tilfellene. Dette er en korreksjonsvirkning godt på høyden med de mest effektive vederlagsreglene vi har. ${ }^{16}$ Betydningen av et slikt funn skal imidlertid ikke overdrives siden funnet ikke bare sier noe om regelen, men om advokatenes evne til å påberope hjemmelen til «rett» tid. Minst like interessant er det derfor å analysere hva som skal til for å vinne frem basert på tredje ledd.

Først omtales de 22 sakene der en utvidet skjevdelingsrett avvises. Disse tegner et bilde av hvilket område som faller utenfor leddets bruksområdet. Når domstolene avviser et krav etter tredje ledd gjøres dette typisk på grunnlag av at det springer ut av et relativt ordinært felleseie og at saksøker kommer helt greit ut av det uten bruk av tredje ledd. Retten begrunner ikke sjelden avvisningen med at begge parter har bidratt etter evne gjennom et ekteskap av varighet. ${ }^{17}$ Det å ha felles barn skaper ofte en situasjon med gjensidige bidrag. Et krav om utvidet rett til skjevdeling avvises tilnærmet konsekvent i slike tilfeller. ${ }^{18}$ Dette blir svært klart når ekteskapet i tillegg er langvarig. Også i relativt korte ekteskap med felles

\footnotetext{
${ }^{15}$ Fredwall (2019) s. 296.

${ }^{16}$ Fredwall (2019) $379-380$

${ }_{17}$ LB-2018-73422, LA-2018-121298, LB-2012-289885, LB-2007-98369, LH-2007-128795, LF-2003-12577, TOSLO2001-4234, LG-2001-1778, Rt. 2001 s. 572 og LA-1998-984.

${ }^{18}$ Felles barn: LB-2018-73422, LB-2016-68323, TOSLO-2015-104214, TOBYF-2014-37819, LB-2012-289885,

TAHER-2012-75180, LB-2011-101920, TOBYF-2009-88115 og LB-2006-33879.
} 
barn, blir imidlertid krav om skjevdeling etter tredje ledd regelmessig avvist. Idet barnet er en del av bildet skal det svært mye til for at skjevdelingsretten utvides. Hensynet til barnet vil svært ofte tale i favør av likedeling mellom foreldrene. Dette er en rettsanvendelse som også harmonerer godt med BK artikkel 3. Selv om artikkelen ikke ble anvendt eksplisitt i noen av sakene, kan mange av dem tilsi at barnets interesse i deling ble vektlagt.

Ekteskap av lang varighet var tydelig representert i de 22 sakene der kravet om utvidet rett til skjevdeling ble avvist. I fem av sakene er ekteskapets lengde særlig understreket og lengde varierte her fra 26 til 40 år. ${ }^{19}$

LG-2001-1778: «As argumenter i så henseende er etter lagmannsrettens syn delvis irrelevante, delvis uten bevismessig dekning og under enhver omstendighet ikke tilstrekkelige til å bringe tredje ledd til anvendelse, verken enkeltvis eller samlet. Eventuell fremtidig arv på ankemotpartens hånd kan ikke tillegges vekt. Det er ikke dekning for de bebreidelser A har fremmet mot B om de økonomiske forhold, herunder at hun ikke har bidradd økonomisk under ekteskapet. Hun har hatt lønnsinntekt hele tiden, og det er på det rene at hennes inntekt i perioder har vært like stor som As pensjon. Hun er den som hver måned betalte blant annet barnehageplass for partenes felles barn. As påstand om at B skal ha forbrukt langt mer enn det familien hadde råd til, slik at han måtte ta av sine skjevdelingsmidler, er heller ikke dokumentert.»

Verne felles hjem bygget opp i et langvarig ekteskap: LA-1998-984: «Lagmannsretten kan heller ikke se at det foreligger slike «sterke grunner» som skjevdeling etter ekteskapsloven § 59 tredje ledd forutsetter. I tillegg til det som fremgår av skifterettens domsgrunner viser lagmannsretten igjen til at en gjeldsforsikring normalt er motivert ut i fra hensynet å sikre partenes felles hjem. I nærværende sak er det tale om et hjem partene bygget opp i fellesskap gjennom et langt ekteskap».

Tekstutdraget fra dommene over illustrerer at i et ekteskap av varighet og med felles barn, avvises ytterligere skjevdeling med hjemmel i tredje ledd. Man kan si at vi her er utenfor bestemmelsens område.

Dette gjelder imidlertid ikke helt konsekvens. Av og til kan nettopp barnehensynet være med på å begrunne en utvidet skjevdelingsrett. Dette er typisk når en utvidet rett til skjevdeling anses nødvendig for å trygge barnets oppvekstsvilkår. ${ }^{20}$

Om sakene der utvidet rett til skjevdeling ble avvist, vurderes samlet, er det grunn til å konkludere med at lovens «sterke grunner» ikke først og fremst bør forstås som uttrykk for en høy terskel, men en påpeking av at bruksområdet for bestemmelsen er snevert og at det

\footnotetext{
${ }^{19}$ LA-2018-1212298, LB-2011-101920, TOSLO-2001-4134, LA-1998-984 og RG-1996-113.

${ }^{20}$ LA-2012-66795 og LA-2000-1700
} 
skal foreligge særegne omstendigheter som kan begrunne at ytterligere midler holdes utenfor deling.

Om paret bare har egne barn og ikke felles barn, er sjansen for å vinne frem økt, men fortsatt kreves det mye av omstendighetene, jf. nærmere behandling av bruksområdet for bestemmelsen i punkt 4. Så langt de sakene der krav etter tredje ledd ble avvist. Hva som kjennetegner de 27 prosent av sakene der ektefellen fikk medhold, skal behandles nærmere i neste punkt. Dette angir samtidig bestemmelsens praktiske bruksområde.

\section{Hva er bruksområdet for $\S 59$ tredje ledd?}

\subsection{Innledning}

I avhandlingen konkluderte jeg på bakgrunn av et samlet rettskildebilde med at bruksområdet for $\S 59$ tredje ledd var «relativt vidt». ${ }^{21}$ Konklusjonen var derved at det mer var snakk om grunner av en viss karakter enn en særlig terskelhøyde for å anvende tredje ledd. I lys av dette har jeg her foretatt en nærmere analyse av samtlige dommer der en utvidet rett til skjevdeling har blitt gitt siden lovens ikrafttredelse.

\subsection{Hvilke særegne grunner preget de sakene der utvidet rett til skjevdeling ble gitt?} Analysen tilsier at enkelte grunner eller omstendigheter har vært særlig egnet til å begrunne utvidet skjevdeling med hjemmel i tredje ledd.

Hensynet til helsemessige forhold og derved en fremtidig svekket økonomisk evne fremstår som en sentral omstendighet som kan begrunne utvidet skjevdeling i denne personens favør. ${ }^{22}$ Dette er ikke overraskende gitt at det forhold at en ektefelle kan ha vanskelig for å fors $\emptyset$ rge seg selv på grunn av sykdom mv. også ble særlig trukket fram i forarbeidene. ${ }^{23}$ I LA2017-343 hadde en mann giftet seg med en afrikansk kvinne. Når ekteskapet ble brutt etter om lag 3 år var mannen smittet med HIV-viruset og hadde mistet retten til å føre anleggsmaskiner som var $n \varnothing d v e n d i g$ for den virksomheten han drev. Agder lagmannsrett kom 2:1 til at det forelå slike særegne grunner i saken som kunne begrunne en utvidet rett til skjevdeling for ham. Dommen vitner imidlertid ikke om noen høy terskel. Også i LA-201266795 la retten vekt på at en utvidet rett til skjevdeling var nødvendig:

\footnotetext{
${ }^{21}$ Fredwall (2019) s. 291.

22 LA-2017-343, LA-2012-66795, LB-2003-17484 (RG 2004 s. 920) og LA-2000-1700.

${ }^{23}$ NOU 1987:30 side 79-80.
} 
«Etter en totalvurdering finner flertallet at As bidrag ved anskaffelsen av boligen, partenes forutsetninger ved anskaffelsen og hvordan de senere har innrettet seg økonomisk, sammenholdt med As vanskelige økonomiske og helsemessige situasjon utgjør sterke grunner for at hele verdien av boligen kan skjevdeles etter ekteskapsloven $\S 59$ tredje ledd. Dette forsterkes ytterligere ved at B har hytteeiendommen som sitt særeie, og at det ikke er andre verdier av betydning til fordeling.»

I dommen fra Agder lagmannsrett hadde paret sørget for at han eide hytteeiendommen og hun eide huset. De hadde imidlertid ikke i tilstrekkelig grad tatt innover seg at hytta var hans særeie mens boligen var felleseie. Om hun med sin vanskelige helsemessige situasjon skulle makte reetablering, hadde hun behov for å kunne skjevdele verdien av felles bolig. Lagmannsretten la avgjørende vekt på dette til tross for at dette gjaldt et felles hjem anskaffet underveis i samlivet. Dommen er også interessant som et eksempel på at det ofte finnes flere grunner for skjevdeling i en og samme sak.

Hensynet til barns oppvekstsvilkår kan også utgjøre en vesentlig grunn for å tilkjenne utvidet skjevdelingsrett. ${ }^{24}$ Dette hensynet kommer ikke like tydelig fram i forarbeidene som hensynet til ektefellens egen forsørgelse. I dag er det grunn til å peke på sammenhengen mellom ekteskapsloven $\S 59$ tredje ledd og FNs barnekonvensjon (BK) artikkel 3 og plikten til å sikre barnets beste som et grunnleggende hensyn ved alle handlinger som berører barn. Også andre menneskerettslige regler beskytter barn også som ledd i et formuerettslig oppgjør. ${ }^{25}$

Agder lagmannsretts dom fra 2012 behandlet ikke BK artikkel 3 direkte, men viste at en slik dom med fordel kunne romme en slik vurdering. Etter endt ekteskap hadde den ene ektefellen svak $\emptyset$ konomi og svak helse. Delingsresultatet hadde imidlertid ikke bare konsekvenser for ektefellene selv, men for deres 10 årige sønn som de hadde delt omsorg for. En særlig svekket økonomisk situasjon for mor ville ramme sønnens oppvekstsvilkår direkte. Også i LA-2000-1700 la retten vekt på at utvidet rett til skjevdeling var nødvendig for å sikre en «nødvendig og nøktern bolig for ektefelle og barn»:

«Fra anskaffelsen av leiligheten og bilen er det bare A som har båret det $\varnothing$ konomiske og praktiske ansvaret for leilighet og bil. Hun har betjent lån og vedlikehold uten noen som helst bistand fra Bs side.

\footnotetext{
24 LA-2012-66795 og LA-2000-1700.

${ }^{25}$ Fredwall, 2019, s. 429-435 der det menneskerettslige vernet om barnet på rettsområdet analyseres.
} 
A har den daglige omsorgen for partenes to fellesbarn, og leiligheten tjener som en nødvendig og nøktern bolig for mor og to barn. B på sin side har gjort lite for å støtte fraskilt ektefelle og barn etter samlivsbruddet, og han har opparbeidet en ikke ubetydelig bidragsgjeld»

Hensynet til å hindre deling av midler som reelt sett er ervervet etter at samlivet er brutt.

Ekteskapslovens hovedregel om likedeling hviler på en forutsetning om økonomisk fellesskap underveis i ekteskapet. I noen ekteskap oppstår aldri et slikt fellesskap, mens det i andre ekteskap kan ha opphørt forut for det som anses som det formelle skjæringstidspunktet. Av og til skyldes dette at et samliv er brutt og gjenopptatt, noen ganger kan det skyldes at ekteskapet har tilknytning til utlandet og at det tar lang tid å få det oppløst og andre ganger fremstår det mer uklart hvorfor prosessfullmektigen ikke har krevd et fremskutt skjæringstidspunkt. Vi har imidlertid flere eksempler på at tredje ledd kan være nyttig for å hindre at midler som er anskaffet mellom det reelle samlivsbruddet og det formelle skjæringstidspunktet, blir delt mellom partene. ${ }^{26}$ En sak fra Oslo tingrett kan illustrere dette. A hadde inngått et ekteskap med en kinesisk borger B i 1998 og det var enighet om at skjæringstidspunktet for samlivets opphør var 30. mars 2002. Det ble imidlertid etter hvert klart at B hele to år $\mathrm{f} \varnothing \mathrm{r}$ det omforente skjæringstidspunktet hadde startet forberedelsene til livet etter ekteskapet og at hun hadde investert i en leilighet sammen med sin søster og med $\varnothing$ konomisk hjelp fra søstrenes far. Retten uttalte følgende om bruken av tredje ledd:

«En slik snever adgang til skjevdeling må imidlertid foreligge i et tilfelle som dette, for midler som er anskaffet etter at samlivet og det $\varnothing$ konomiske fellesskap i realiteten var brutt. Det foreligger da "sterke grunner» for skjevdeling etter $\S 59$ tredje ledd selv om partene skulle være enige om at det formelle «skjæringstidspunkt» etter $\underline{\S 60}$ bokstav a) kom på et senere tidspunkt» ${ }^{27}$

Hensynet til å sikre deling i tråd med partenes forutsetninger eller hindre urimelighet som følge av tilfeldige disposisjoner, fremstår som en ytterligere sentral begrunnelse for å akseptere en utvidet rett til skjevdeling. ${ }^{28}$ I LA-2017-34372 hadde partene fors $\varnothing$ kt å opprette ektepakt med fullstendig særeie, men uten at fors $\varnothing$ kte resulterte i en formriktig og bindende ektepakt. Dette fremstår som en vesentlig grunn for flertallet (2:1) som kommer til at mannen har rett til utvidet skjevdeling på bekostning av hans kone etter et kortvarig ekteskap. Ved å anvende tredje ledd nås en løsning som er tett opptil den Iøsningen paret selv fors $\varnothing$ kte å avtale gjennom ektepakten.

\footnotetext{
${ }^{26}$ LA-2009-136556, TOSLO-2005-5687 og LA-2000-1700.

27 TOSLO-2005-5687.

28 LA-2017-34372, LA-2012-66795, LG-2010-66795, LA-2009-136556, LB-2003-17484/RG 2004 s. 920.
} 
Dommen i LA-2012-66795 gav som nevnt et eksempel på en situasjon der partene har planlagt at den ene skal eie hytta og den andre boligen, men der de ikke hadde forutsett konsekvensene av at hytta var gjort til mannens særeie, mens boligen forble i felleseie om enn på kvinnens rådighetsdel. Dette ble korrigert gjennom bruk av tredje ledd.

I en dom fra 2009 også denne gang fra Agder lagmannsrett ble samlivet mellom partene først brutt og så gjenopptatt og deretter brutt igjen. ${ }^{29}$ Den kvinnelige ektefellen hadde i den første perioden der det var brudd mellom partene, investert i en egen leilighet. Som følge av at samlivet ble gjenopptatt, ville lovens hovedregel tilsi at verdien av leiligheten skulle likedeles. En slik deling fremsto i strid med partenes forutsetninger på disposisjonstidspunktet og retten uttalte følgende om bruksområdet for $\S 59$ tredje ledd:

«Vi har i vår sak å gjøre med en situasjon der sterke rimelighets- og rettferdighetshensyn tilsier at verdien av leiligheten skjevdeles til fordel for B. Den lange separasjonstiden har vært et vesentlig moment i vurderingen, og grunnlaget for å falle tilbake på formuesordningen fra før separasjonen gjør seg da ikke like sterkt gjeldende». ${ }^{30}$

I en dom fra 2003 la også Borgarting lagmannsrett særlig vekt på at det var tilfeldigheter som gjorde at kvinnen ikke har rett til å skjevdele etter $\S 59$ første ledd. Retten la i tillegg vekt på at ekteskapet hadde vært kortvarig (6 år) og at den kvinnelige ektefellen og det yngste barnet (7 år) ville få en vanskelig livssituasjon. Dette ble korrigert ved bruk av tredje ledd: ${ }^{31}$

«Hadde sluttvederlaget blitt innvilget få måneder tidligere, og hadde B benyttet vederlaget til innfrielse av all gjeld på leiligheten - kr 210.000 - ville hun på skiftet kunne ha skjevdelt hele verdien av leiligheten i medhold av den ubetingede rett hun ville hatt etter første ledd $\mathrm{i}$ ekteskapsloven § 59. Slik situasjonen ble innfridde hun i 1996 diverse lån for ca kr 78.000, herunder etableringslånet på leiligheten, mens hun i 1998 anvendte ca kr 92.000 til det mislykkede eiendomsprosjekt som ektefellene da involverte seg i. Disse omstendigheter viser at det kan synes langt på vei tilfeldig at $\mathrm{B}$ kom i den situasjon som er med hensyn til skjevuttak av leiligheten. Dette er, slik lagmannsretten ser det, et ikke uvesentlig moment ved en vurdering av rimeligheten i det delingskrav hun fremsetter på skiftet»

Dommen fra 2003 er også et eksempel på at tredje ledd anvendes som et supplerende grunnlag for skjevdeling der retten til skjevdeling etter første ledd har gått tapt som følge av mer tilfeldige disposisjoner.

\footnotetext{
${ }^{29}$ LA-2009-136556

${ }^{30}$ LA-2009-136556.

${ }^{31}$ LB-2003-17484/RG 2004-920.
} 
Hensynet til å sikre balanse når den enes midler er delingsmidler, mens den andres holdes utenfor deling etter giver eller arvelaters bestemmelse kan også være en grunn til å anvende tredje ledd. Denne bruken av bestemmelsen var påtenkt allerede i forarbeidene. ${ }^{32}$ Et slikt hensyn kan fremstå som rimelig gitt at ektefellene selv ofte ikke har kontroll over at det blir fastsatt særeie for enkelte eiendeler. Og det er nettopp støtten for en slik tilnærming i forarbeidene som kan forsvare løsningen i LE-2007-30335. Denne dommen er etter mitt syn den dommen som går lengst i å tilkjenne en utvidet rett til skjevdeling. Retten fant her at det forelå «sterke grunner» for at ektefellen B skulle kunne få holde sin kontant innbetaling ved kjøpet av slektsgården Y på 346148 kroner og hennes kjøp av bil til A til 400000 kroner utenfor deling. Begge disse disposisjonene ble foretatt underveis i ekteskapet og man ville normalt forvente likedeling. Retten begrunnet den utvidende retten til skjevdeling blant annet med det særeiet som var fastsatt for A:

«Det må i denne sammenheng også tas i betraktning at A har overtatt som sitt særeie halvparten av en eiendom i Trysil».

Jeg forstår dommen slik at terskelen for å la henne beholde verdier utenfor deling senkes fordi han allerede kan beholde verdier udelt. Det at både overføringen av gården (til henne) og hytta (til ham) har preg av generasjonsskifte, styrker nok lagmannsretten tilbøyelighet til å senke terskelen etter tredje ledd slik at disse likeartede situasjonene kunne behandles likt.

Til sist viser materialet at utenlandsk tilknytning preger en andel av sakene der utvidet skjevdeling er innvilget. ${ }^{33}$ En utenlandsk tilknytning for en eller begge parter kan gi andre forventninger til rettsordenen og partenes forutsetninger kan også være andre. Ekteskapene i de tre konkrete sakene der en eller begge har utenlandsk opprinnelse, er alle av kort varighet og flere av dem synes å være mer preget av behovet for å sikre oppholdstillatelse enn av et samliv med integrert $\varnothing$ konomi, som ellers preger flertallet av ekteskapene. ${ }^{34}$ Dette gjør ikke en utenlandsk tilknytning til en mark $\varnothing r$ for $\varnothing k t$ bruk av skjevdeling, men kanskje til en mark $\emptyset r$ for behovet for å unders $\emptyset$ ke partenes forutsetninger nærmere. I LA-2017-34372 hadde partene f.eks. opprettet en ugyldig ektepakt der de fors $\varnothing$ kte å avtale fullstendig særeie. En slik ugyldig ektepakt kan ses som et uttrykk for ektefellenes felles forutsetninger om den $\varnothing$ konomiske ordningen mellom dem. Dette kan være et moment ved vurderingen av

\footnotetext{
32 NOU 1987:30 side 79-80.

${ }^{33}$ LA-2017-34372, TOSLO-2005-5687 og LA-2000-1700.

${ }^{34}$ Fredwall (2019) s. $129-141$.
} 
grunnene for en utvidet rett til skjevdeling - og ikke minst om partene har innrettet seg i tillit til (den ugyldige) avtalen.

Forarbeidenes og til dels teoriens forventning om at bestemmelsen skulle sikre at pågående næringsvirksomhet gjennom redusert likedeling har imidlertid ikke vist seg praktisk. ${ }^{35}$ Vi har riktignok en Høyesterettsdom avsagt på grunnlag av forrige lov, der en ektefelle fikk holde dels en mindre næringsvirksomhet og en fritidseiendom utenfor deling som konsekvens av at bolig mv. var ektefellens særeie, men vi har ingen dom etter gjeldende lov der en ektefelle gis rett til å holde næringsvirksomhet utenfor deling ${ }^{36}$ Dette synes ikke først og fremst fordi slik næringsvirksomhet deles, men enten fordi virksomheten er særeie eller sikret på annen måte, tilhørte eieren forut for ekteskapet eller er mottatt ved arv eller gave slik at den uansett kan skjevdeles. I de få sakene der utvidet skjevdelingsrett er påberopt av en næringsdrivende ektefelle har dette stort sett blitt avvist. ${ }^{37}$ Og i de få sakene der utvidet skjevdeling er tilkjent, har dette som oftest kommet den andre ektefellen til gode og som en kompensasjon for at næringsvirksomheten allerede holdes utenfor deling. ${ }^{38}$ Dette utelukker ikke i prinsippet at arten av eiendelen, og da særlig betydningen av en pågående næringsvirksomhet, kan bli vektlagt som et moment i en fremtidig sak, men det viser at dette ikke har vært et praktisk bruksområde til nå. ${ }^{39}$

\subsection{Oppsummerende vurdering}

Regelen i § 59 tredje ledd har nå vært i kraft i drøyt 25 år. Det er en regel som ikke er egnet for partene egen bruk. Der parter inngår forlik basert på juridiske råd, er det grunn til å forvente at man benytter avtalefriheten heller enn en fintolket tredje ledd. En analyse av rettspraksis er derved viktig for å klarlegge hvordan regelen har blitt forstått og anvendt.

\footnotetext{
${ }^{35}$ NOU 1987: 30 s. 80 .Utvalget peker her på at der «...virksomheten skal fortsette, [kan ektefellen] ha vanskelig for å utløse den annen ektefelle fullt ut». Og at det i et tilfelles som dette kan «være rimelig at en ektefelle får beholde mer enn halvparten av midler denne ektefellen har lagt opp mens ekteskapet har vart». Se også Lødrup/Sverdrup (2016) s. 281 og Holmøy/Lødrup (2001) der arten av de eiendelene kravet refererer seg til omtales.

${ }^{36}$ Rt. 1991 s. 447.

${ }^{37}$ Verken i Rt. 2001-572 eller i LB-2018-73422 fikk den næringsdrivende medhold. Det er imidlertid et visst preg av vern om pågående næringsdrift i LE-2007-30335 der blant annet kontantbidraget ved overtakelsen av en gård ble akseptert holdt utenfor deling. I denne saken var imidlertid hensynet til balansen mellom hver av partenes delingsmidler og ikke-delingsmidler mer fremtredende, jf. over.

${ }^{38}$ RG 2004 s. 920 der mannens næringsvirksomhet ble holdt utenfor deling etter $\S 59$ første ledd, fikk kvinnen rett til å skjevdele også den belånte delen av leiligheten hun hadde brakt inn med hjemmel $i$ tredje ledd.

${ }^{39}$ Fredwall, 2019, s. 295
} 
Analysen over viser at det særlig er tre forhold som begrunner utvidelse av skjevdelingsretten. ${ }^{40}$ Dette er for det $f \varnothing r s t e$ for å sikre tilstrekkelig levekårene for ektefellen og barn ektefellen har omsorg for (helt eller delt). Som nevnt vil det også foreligge en plikt for domstolen til å vurdere hensynet til barnet, jf. BK artikkel 3. Det er for det andre hensynet til å holde midler utenfor deling som basert på partenes felles forutsetninger ikke skulle være i felleseie. Disse forutsetningene kan ha sitt utspring i et samliv som reelt sett er brutt, en ektepakt partene trodde var gyldig eller en annen form for rettsvillfarelse som tilsier at de rettslige konsekvensene av disposisjonene har blitt andre enn det ektefellene forutsatte. Det er for det tredje hensynet til å skape balanse mellom delingspliktige midler og midler som en ektefelle kan holde utenfor deling.

Dommene på dette feltet kan alle plasseres i minst og ofte flere av disse hovedkategoriene.

\section{Samspillet mellom reglene om skjevdeling, vederlag og retten til forlodds uttak}

Ekteskapslovens § 59 tredje ledd er ikke alene om å gi hjemmel til å holde midler ervervet underveis i ekteskapet utenfor deling i et ekteskap med felleseie. I dagens ekteskapslov kan både reglene om rett til forlodds uttak i § 61, vederlag med hjemmel i § 63 annet ledd og $\S$ 59 tredje ledd på nærmere vilkår gi hjemmel til å holde midler utenfor deling. Disse regelsettene har blitt til på ulik tid og med ulik begrunnelse. Alle tre kan fremstå som velbegrunnet. Det er likevel ikke til å komme forbi at tre relativt kompliserte og skjønnsmessige regel(-sett) for å sikre at felleseiemidler holdes utenfor deling, kan fremstå som unødvendig mye.

Særlig vederlagsreglene og skjevdelingsreglene har overlappende funksjoner. Positivt sett kan dette gi en dynamikk og kanskje noen fortrinn i enkelte saker, men som oftest fremstår det å legge flere regler oppå hverandre som tungvint. Spørsmålet er om man kunne tenke seg en enklere måte.

\footnotetext{
${ }^{40}$ Fredwall, 2019, s. 291-296 er bestemmelsen dels tiltenkte, dels faktiske bruksområdet beskrevet gjennom seks punkter. Punkt 1 tilsvarer punkt 1 også her, mens punkt 2 her særlig favner punkt 4 og 6 i avhandlingen og mens punkt 3 her i stor grad svarer til punkt 3 i avhandlingen. Forskjellen oppstår fordi redegjørelsen for bruksområdet $\mathrm{i}$ avhandlingen er basert på summen av forarbeidenes forutsetninger om bruken og supplert av rettspraksis. Analysen i punkt 5 er basert på rettspraksis alene, men samtidig basert på samtlige publiserte dommer. Dette materialet artikkelen hviler på forteller hvordan bestemmelsen faktisk har blitt brukt heller enn hvordan den kunne ha blitt brukt.
} 
I 2010 inngikk Tyskland og Frankrike en konvensjon kalt The Optional Matrimonial Property Regime. ${ }^{41}$ Dette var en konvensjon som ektefeller med tilknytning til de to land i ektepakts form kunne bestemme at skulle gjelde for seg istedenfor gjeldende familielovgivning. Formålet med en slik konvensjon var å lette fri bevegelse mellom sentrale EU-land og dernest å kunne brøyte vei for en fremtidig materiell regulering av familieretten på europeisk plan. Det siste er det vanskelig å få til. Men denne konvensjonen er basert på en enkel struktur og har kun en korreksjonsmekanisme. Den er basert på en tilvekst-modell slik at det fastsettes hvilken netto formuesverdi hver av partene hadde ved ekteskapets inngåelse, deretter hvilken nettoverdi hver av den hadde ved samlivets opphør. Differansen mellom disse størrelsen viser hvor mye partene har akkumulert underveis i ekteskapet, og dette beløpet skal i utgangspunktet deles med partneren. Men om en av ektefellene har foretatt disposisjoner som har svekket dette delingsgrunnlaget, skal verdien av den formuen ektefellen hadde ved opphør $\varnothing$ kes med det «tapte» beløpet slik at det blir tilsvarende mer til deling.

Det følger av 2010-konvensjonens artikkel 10 (2) at denne sluttverdien skal økes med verdien av gaver overført til tredjepart, bortsett fra om det dreide seg om sedvanlige gaver eller overføring av livsarvinger av verdier ektefellen hadde fra før. Dernest skal sluttverdien $\emptyset$ ke med verdien av tap som den andre direkte eller indirekte har påført den andre den andre og med verdier som har forsvunnet. ${ }^{42}$

Et enkelt eksempel. A og B beveger seg mot et samlivsbrudd. B overfører 200000 til sin bror omlag et halvt år før bruddet er et faktum. I dette tilfellet ville B få lagt beløpet på 200000 på toppen av sin sluttformue, slik at hun må betale 100000 ekstra til A som ledd i delingen.

Jeg tror ikke akkurat denne løsningen hadde passet for norske forhold. Men modellen er interessant i sin enkelhet. Konvensjonen regulerer på mange måter et regnestykke og om en ektefelle har redusert den andres delingsforventning så «rettes» dette matematisk ved at den nominelle sluttformuen $\varnothing$ kes med den konsekvens at delingsforventningen vernes. Ved

\footnotetext{
${ }^{41}$ Abkommen zwischen der Bundesrepublik Deutschland und der Französischen Republik über den Güterstand der Wahl-Zugewinngemeinschaft, 13. januar 2010.

${ }^{42}$ Maria Giovanna Cubeddu Wiedemann (2014) The Optional Matriomonial Property Regime s. $213-214$. Her pekes det på at alternativet forsvunnet også dekker et hensynsløst forbruk foretatt i lys av et kommende brudd.
} 
å anvende en slik struktur, kunne i og for seg ethvert korreksjonsgrunnlag gi rett til å justere sluttformuen opp eller ned.

I en eventuell ny lov ville det vært grunn til å vurdere om også ekteskapslovens korreksjonsmekanismer kunne gjøres færre, enklere og mer effektive.

\section{Konklusjon}

Den grunnleggende forutsetningen for å ta $\S 59$ tredje ledd i bruk er at paret er gift og har felleseie. I avhandlingen konkluderte jeg med at bestemmelsen fremstod som en «vesentlig sikkerhetsventil» for de «atypiske forholdene».43 Dette inntrykket er befestet gjennom den videre analysen foretatt her. Analysen har gitt grunnlag for å beskrive det atypiske nærmere. Ett fellestrekk har det vært mulig å finne i disse atypiene. Tredje ledd har sitt bruksområde først og fremst der man av flere, samtidige grunner befinner seg i formuesfellesskapets randsone. Dette kan være kombinasjoner av forhold som at ekteskapet har vært kortvarig og nærmest har endt før det har begynt, at samlivet reelt sett har vært over og at de aktuelle investeringene er foretatt med tanke på livet etter bruddet, at partene har innrettet seg basert på en atskilt økonomi, men der dette ikke har vært i tråd med de rettslige realitetene eller der giver eller arvelater har påbudt at verdier ikke deles slik at rest-formuesfellesskapet i dette tilfellet har blitt haltende. Og motsatt der vi befinner oss i ordinære ekteskap med felleseie, felles barn og en smule varighet, er vi nesten alltid utenfor tredje ledds rekkevidde. Det at lysten til å dele ikke er der, er i denne sammenheng ikke relevant. For som Lødrup/Sverdrup har påpekt, bestemmelsen kan ikke brukes «fordi man misliker at en ektefelle etter skilsmissen får betydelige midler som den andre har skapt under ekteskapet». ${ }^{44}$ Når det hevdes at tredje ledd er en snever unntaksregel, sier det derved først og fremst noe om regelens bruksområdet. Bruksområdet for tredje ledd er snevrere enn bruksområdet for første og annet ledd.

Det er ikke nødvendigvis holdepunkter for at det «antakelig» skal mer til å vinne fram med hjemmel i tredje ledd enn annet ledd. Analysen av rettspraksis viser at om saksforholdet er slik at vi befinner oss i felleseiets randsone, så er terskelen for å anvende tredje ledd ikke svært høy.

\footnotetext{
${ }^{43}$ Fredwall, 2019, s. 296

${ }^{44}$ Lødrup/Sverdrup (2016) Familieretten 8. utg. s. 280
} 
Rettspraksis tilsier at tredje ledd anvendes som en korreksjonsmekanisme for å sikre balanserte og rimelige oppgjør. Et grunnleggende hensyn i så måte er at ektefellens og barnas fremtidige levekår sikres. Dette hensynet understøttes også av grunnleggende menneskeretter. Min konklusjon er derfor at $\S 59$ tredje ledd slik den er anvendt, ikke er i strid med menneskerettene - til tross for sin ordlyd.

Ekteskap er ulike. Loven er derved tjent med å ha sikkerhetsventiler. Spørsmålet er imidlertid om den er tjent med å ha så vidt mange, ulike og spesifikke mekanismer som i dag. Mitt svar er nei. Brukerperspektivet tilsier at retten til forlodds uttak, utvidet skjevdeling og vederlag avstemmes mot hverandre og helst forenkles. ${ }^{45}$

\footnotetext{
${ }^{45}$ Sml. Fredwall (2019) s. 311-321 og 445-446 der behovet for revisjon av skjevdelingsreglene og vederlagsreglene behandles.
} 